\title{
A literature review of children's and young people's participation in decisions relating to health care
}

\author{
Lucie Moore and Susan Kirk
}

Aims and objectives. To review and critique the research literature on children's and young people's participation in health care decision-making, to highlight gaps in the research and to identify implications for nursing practice.

Background. Children have a right to participate in decisions about their lives. The recognition of this, along with greater acknowledgement of children's capabilities, has led to an increasing awareness that children's views must be given value in both national policy and individual decisions. Health professionals have also been given explicit direction to ensure that children are actively involved in decision-making.

Design. Literature review.

Method. Search of electronic databases and manual searching of journals and reference lists between 1990-2009.

Results. Children want to be involved in discussions about their care but it is unclear to what extent this happens in practice. The research conducted has interpreted participation in different ways. Studies have compared decisions of differing importance in terms of risk and many have a wide age range in their samples, including children who are arguably too young for meaningful participation. However, this heterogeneity is often overlooked in the reporting of studies. Aspects of practice which can help or hinder participation are identified but there is little evidence on the outcome benefits of participation. In addition, there has been an over-reliance on interviews as the method of data collection.

Conclusions. Research using a combination of observation and interviewing would provide more in-depth knowledge about participation in practice. In addition, studies should consider decisions of similar consequence and children at an age when participation is appropriate.

Relevance to clinical practice. The need for health professionals to ensure children are protected is undisputed but should not prevent children's rights to participate from being enacted. Practitioners, therefore, need further guidance on how to facilitate the participation of children.

Key words: children, decision-making, health care, nurses, nursing

Accepted for publication: 16 September 2009

\section{Introduction}

In recent years health professionals in the UK have been given explicit direction by the Department of Health to ensure that children in health care services are able to participate in decision-making processes in a meaningful way. The chil- dren's National Service Framework (NSF), which aims to improve services for children (DH; DfES 2004), states that children and young people should be actively involved in decisions about their health and well-being pointing out that this right is conferred on them by the United Nations Convention on the Rights of the Child 1989 (UNCRC).
Authors: Lucie Moore, BSc, MSc, RN, RGN, Lecturer, The School of Nursing, Midwifery and Social Work, The University of Manchester, University Place; Susan Kirk, MSc, BNurs, PhD, RN, RM, RHV, DNCert, Senior Lecturer, The School of Nursing, Midwifery and Social Work, The University of Manchester, University Place, Manchester, UK
Correspondence: Lucie Moore, Lecturer, The School of Nursing, Midwifery and Social Work, The University of Manchester, University Place, Oxford Road, Manchester M13 9PL, UK. Telephone: +4401613067742.

E-mail: lucie.moore@manchester.ac.uk 
Explicitly driven by Article 12 of the UNCRC, the NSF also makes reference to the focus in recent years on the development of partnerships between patients and health professionals, a central theme in the modernisation of the National Health Service (NHS) as first described in the NHS Plan (DH 2000). Patients are thus increasingly encouraged towards a more active involvement in their health care, sharing information, responsibility and decision-making with health care professionals (DH 2001, Coulter 2004, Staniszewska \& West 2004). Children are also seen as service users in their own right and can, therefore, expect the same rights to consultation and involvement in decision-making as adult partners (Kirby et al. 2003, Lightfoot \& Sloper 2003, Sinclair 2004).

Whilst it has been suggested that health care workers lead the way in respecting young people's rights (Alderson 2002), the achievement of this in practice can be problematic as conflict occurs with the requirement of both the UNCRC and the Children Act 1989 that the child's best interests are the primary consideration (Lansdown 2000). This presents tensions for health care professionals who try to promote the autonomy of children and young people whilst at the same time ensuring that all actions and decisions are in the child's best interests (Bricher 2000).

To promote the autonomy of children, health professionals must first assess the competency of the child (Baxter et al. 1998). The legal view of competency has changed from an emphasis on a stated age of consent to a consideration of the individual's ability or competency to consent (Alderson 1993). A growing body of literature emphasises the capabilities of children in making valuable contributions to decisions about their care (Weithorn \& Campbell 1982, Alderson 1993, Alderson et al. 2006). The capacity for abstract thought, described by Piaget as developing in the formal operational stage beginning around 12 years of age, allows young people to consider short- and long-term consequences and weigh up and choose between different courses of action (Weithorn \& Campbell 1982, Beidler \& Dickey 2001). Furthermore, greater competency can be found in children with experience of severe illness or disability with children as young as four years demonstrating the ability to make informed decisions about their care (Alderson 1993, Alderson et al. 2006). However, in the absence of any recognised test to determine competency, practitioners are left to make subjective judgements. In so doing, and in the name of best interests, the wishes of children can be and frequently are overruled by adults (Lansdown 2000, James \& James 2004). Arguably, this renders any apparent autonomy the child may have in health care as ultimately meaningless, leading to the repression of the child hidden under the acceptable guise of protection. In so doing the right of children to participate, as set out in legislative terms in the UK and internationally, is not upheld.

\section{Aims}

The aims of the review were to critique the research literature on children's and young people's participation in decision-making related to their health care, to highlight gaps in the research and to identify the implications for nursing practice.

\section{Objectives and methods}

The review considered several questions. Do children want to participate in decision-making and to what extent are they given opportunities to do so in practice? What are the barriers to and enablers of participation? What are the benefits and disadvantages to children and young people who participate? A systematic search strategy was developed to identify relevant studies. The following health and social science electronic databases were searched: CINAHL: Cumulative Index to Nursing and Allied Health Literature; MEDLINE; The Cochrane Library; British Nursing Index; PsycInfo; Sociological Abstracts; Sociology: A SAGE FullText Collection; Social Sciences Index; Social Sciences Citation Index and ASSIA: Applied Social Sciences Index and Abstracts. In addition key journals were hand searched, and reference lists reviewed for additional studies. Search terms used included children, participation, decision-making, involvement, consent, competence, autonomy, children's rights, health care, UNCRC, Children Act, young people, adol*, child*. Studies were included if they reported empirical research (qualitative or quantitative) relating to the aims and objectives of the review; were published between 19902009; and examined the participation of children and young people under 18 years in both primary and secondary health care settings with either acute or chronic conditions. Studies were excluded if they were literature reviews or expert commentaries (although their reference lists were examined to identify studies for the review); were not published in the English language; focussed on young people's participation in planning, developing or evaluating health services (rather than their personal health care).

The search identified 25 empirical research studies (Table 1). Twenty studies used qualitative methods and five studies used a mixed methods approach. Samples vary from children with acute illnesses to those with long-term or lifethreatening conditions, and sometimes both groups are included in the same study. Ages of the children studied, where stated, range from $<1-18$. 
Table 1 Studies included in the review

\begin{tabular}{|c|c|c|c|c|}
\hline Author, date, country & Research question/aim & $\begin{array}{l}\text { Research approach and } \\
\text { methods }\end{array}$ & Participants & $\begin{array}{l}\text { Acute/chronic } \\
\text { illness }\end{array}$ \\
\hline Alderson (1993), UK & $\begin{array}{l}\text { To explore the views of children } \\
\text { and parents on consent }\end{array}$ & $\begin{array}{l}\text { Qualitative, structured } \\
\text { interviews }\end{array}$ & $\begin{array}{l}n=20 \text { children } \\
\text { aged } 8-15 \\
n=104 \text { mothers } \\
n=38 \text { fathers }\end{array}$ & Chronic \\
\hline $\begin{array}{l}\text { Alderson et al. (2006), } \\
\text { UK }\end{array}$ & $\begin{array}{l}\text { To investigate the views of } \\
\text { children with diabetes about their } \\
\text { condition and ways in which they } \\
\text { share managing their medical and } \\
\text { health care with adults }\end{array}$ & $\begin{array}{l}\text { Qualitative, semi-structured } \\
\text { interviews }\end{array}$ & $\begin{array}{l}n=24 \text { children, } \\
\text { aged } 3-12\end{array}$ & Chronic \\
\hline $\begin{array}{l}\text { Angst and Deatrick } \\
\text { (1996), USA }\end{array}$ & $\begin{array}{l}\text { To examine the involvement of } \\
\text { school-age children and } \\
\text { adolescents in decisions about } \\
\text { their own health care }\end{array}$ & Qualitative, interviews & $\begin{array}{l}n=20 \text { children, } \\
\text { aged } 7-11, \text { and } \\
n=40 \text { parents } \\
n=8 \text { children, aged } \\
9-19, \text { and } n=8 \\
\text { parents }\end{array}$ & Chronic \\
\hline $\begin{array}{l}\text { Beresford and Sloper } \\
\text { (2003), UK }\end{array}$ & $\begin{array}{l}\text { To explore the experiences of } \\
\text { chronically ill adolescents in } \\
\text { communicating with health } \\
\text { professionals }\end{array}$ & $\begin{array}{l}\text { Qualitative, interviews and } \\
\text { group discussion }\end{array}$ & $\begin{array}{l}n=63, \text { age } \\
11-16 \text { years }\end{array}$ & Chronic \\
\hline $\begin{array}{l}\text { Bjork et al. (2006), } \\
\text { Sweden }\end{array}$ & $\begin{array}{l}\text { To describe young children's needs } \\
\text { after being diagnosed with cancer }\end{array}$ & $\begin{array}{l}\text { Qualitative, non-partici } \\
\text { pant, unstructured } \\
\text { observation }\end{array}$ & $\begin{array}{l}n=12 \text { children, } \\
\text { under } 7 \text { years }\end{array}$ & $\begin{array}{l}\text { Chronic/life } \\
\text { threatening }\end{array}$ \\
\hline $\begin{array}{l}\text { Bricher (2000), } \\
\text { Australia }\end{array}$ & $\begin{array}{l}\text { To explore the experiences of } \\
\text { paediatric nurses }\end{array}$ & $\begin{array}{l}\text { Qualitative, open, } \\
\text { unstructured interviews }\end{array}$ & $\begin{array}{l}n=6 \text { paediatric } \\
\text { nurses }\end{array}$ & N/A \\
\hline Carter (2002), UK & $\begin{array}{l}\text { To explore from children's and } \\
\text { families' perspectives on the } \\
\text { impact of living with pain, } \\
\text { focus on the role of professionals } \\
\text { in the medical encounter }\end{array}$ & $\begin{array}{l}\text { Qualitative, journals } \\
\text { and interviews }\end{array}$ & $\begin{array}{l}n=3 \text { children, aged } \\
12-13 \text { and their } \\
\text { families }\end{array}$ & Chronic \\
\hline Cox et al. (2007), USA & $\begin{array}{l}\text { To objectively assess the amount } \\
\text { of deliberation; the involvement } \\
\text { of parents and children in } \\
\text { deliberation; and how } \\
\text { deliberation is associated } \\
\text { with child, physician, parent } \\
\text { and visit characteristics }\end{array}$ & $\begin{array}{l}\text { Quantitative, videotaping } \\
\text { of outpatient encounters }\end{array}$ & $\begin{array}{l}n=101 \text { children, } \\
\text { mean age } 5 \cdot 4 \text { years, } \\
n=15 \text { doctors }\end{array}$ & Acute \\
\hline $\begin{array}{l}\text { Cox and Raaum (2008), } \\
\text { USA }\end{array}$ & $\begin{array}{l}\text { To objectively evaluate the } \\
\text { discussion of alternatives, risks } \\
\text { and benefits in paediatric acute } \\
\text { care visits, with a specific focus } \\
\text { on the involvement of parents and } \\
\text { children in these discussions. To } \\
\text { examine how characteristics of } \\
\text { the participants and the visit are } \\
\text { associated with these discussions } \\
\text { and with parent or child } \\
\text { involvement in the discussions }\end{array}$ & $\begin{array}{l}\text { Quantitative, videotaping } \\
\text { of outpatient encounters }\end{array}$ & $\begin{array}{l}n=98 \text { videotaped } \\
\text { consultations, } \\
n=15 \text { doctors } \\
\text { children aged } 0-17\end{array}$ & Acute \\
\hline Cox et al. (2009), USA & $\begin{array}{l}\text { To examine how child age and } \\
\text { parental education affect } \\
\text { participation }\end{array}$ & $\begin{array}{l}\text { Quantitative, videotaping } \\
\text { of outpatient encounters }\end{array}$ & $\begin{array}{l}n=100 \text { children, } \\
\text { mean age } 5 \cdot 4 \text { years, } \\
n=15 \text { doctors }\end{array}$ & Acute \\
\hline Coyne (2006), Ireland & $\begin{array}{l}\text { To explore children's, parents' and } \\
\text { nurses' views on participation in } \\
\text { care in the healthcare setting }\end{array}$ & $\begin{array}{l}\text { Qualitative, in-depth } \\
\text { interviews and participant } \\
\text { observation }\end{array}$ & $\begin{array}{l}n=11 \text { children, } \\
\text { aged } 7-14 * \\
n=10 \text { parents } \\
n=12 \text { nurses }\end{array}$ & $\begin{array}{l}\text { Acute and } \\
\text { chronic }\end{array}$ \\
\hline
\end{tabular}


Table 1 (Continued)

\begin{tabular}{|c|c|c|c|c|}
\hline Author, date, country & Research question/aim & $\begin{array}{l}\text { Research approach and } \\
\text { methods }\end{array}$ & Participants & $\begin{array}{l}\text { Acute/chronic } \\
\text { illness }\end{array}$ \\
\hline $\begin{array}{l}\text { Dixon-Woods et al. } \\
\text { (2002), UK }\end{array}$ & $\begin{array}{l}\text { To investigate the views of } \\
\text { children, young people and their } \\
\text { parents on primary care services } \\
\text { for childhood asthma... and to } \\
\text { identify the dimensions of care } \\
\text { which they see as important }\end{array}$ & $\begin{array}{l}\text { Qualitative, semi-structured } \\
\text { interviews }\end{array}$ & $\begin{array}{l}n=20 \text { families, } \\
\text { children aged } \\
8-16 \text { years }\end{array}$ & Chronic \\
\hline $\begin{array}{l}\text { Hallstrom and Elander } \\
\text { (2004), Sweden }\end{array}$ & $\begin{array}{l}\text { To explore what kind of decisions } \\
\text { and how these decisions were } \\
\text { made during a child's } \\
\text { hospitalisation }\end{array}$ & $\begin{array}{l}\text { Qualitative, non- } \\
\text { participant observation }\end{array}$ & $\begin{array}{l}n=24 \text { children, } \\
\text { aged } 5 \text { months- } \\
18 \text { years, and their } \\
\text { parents }\end{array}$ & $\begin{array}{l}\text { Acute and } \\
\text { chronic }\end{array}$ \\
\hline Kelsey et al. (2007), UK & $\begin{array}{l}\text { To explore young people's } \\
\text { perceptions of their involvement } \\
\text { in healthcare decisions affecting } \\
\text { their management of care }\end{array}$ & $\begin{array}{l}\text { Qualitative, focussed } \\
\text { interviews and audio diaries }\end{array}$ & $\begin{array}{l}n=10 \text { young } \\
\text { people, aged } 12-16\end{array}$ & Acute \\
\hline $\begin{array}{l}\text { Lambert et al. (2008), } \\
\text { Republic of Ireland }\end{array}$ & $\begin{array}{l}\text { To explore the nature of } \\
\text { communication for children } \\
\text { admitted to a specialist } \\
\text { children's hospital }\end{array}$ & $\begin{array}{l}\text { Qualitative, semi- } \\
\text { participant observation, } \\
\text { unstructured interviews, } \\
\text { draw and write technique } \\
\text { and a child-friendly quiz }\end{array}$ & $\begin{array}{l}n=49 \text { children, } \\
\text { aged } 6-16\end{array}$ & Acute chronic \\
\hline Noyes (2000), UK & $\begin{array}{l}\text { To explore young ventilator- } \\
\text { dependent people' views and } \\
\text { experiences of health care }\end{array}$ & $\begin{array}{l}\text { Qualitative, focused } \\
\text { interviews }\end{array}$ & $\begin{array}{l}n=18 \text { children, } \\
\text { aged } 6-18, \text { and } \\
\text { family members of } \\
15 \text { children }\end{array}$ & Chronic \\
\hline $\begin{array}{l}\text { Runeson et al. (2000), } \\
\text { Sweden }\end{array}$ & $\begin{array}{l}\text { To identify everyday situations in } \\
\text { medical and nursing care in which } \\
\text { children had been allowed to have a } \\
\text { voice or been denied the right }\end{array}$ & Qualitative, interviews & $\begin{array}{l}n=26 \text { children, } \\
\text { aged } 6-17, \text { and } \\
n=21 \text { parents }\end{array}$ & $\begin{array}{l}\text { Acute and } \\
\text { chronic }\end{array}$ \\
\hline $\begin{array}{l}\text { Runeson et al. (2001), } \\
\text { Sweden }\end{array}$ & $\begin{array}{l}\text { To identify factors of importance } \\
\text { for children's participation in } \\
\text { medical and nursing care }\end{array}$ & $\begin{array}{l}\text { Qualitative, critical incident } \\
\text { technique }\end{array}$ & $\begin{array}{l}n=92 \text { doctors } \\
\text { nurses, play therapists } \\
\text { and psychologists }\end{array}$ & N/A \\
\hline $\begin{array}{l}\text { Runeson et al. (2002a), } \\
\text { Sweden }\end{array}$ & $\begin{array}{l}\text { To describe the degree of } \\
\text { participation by children in } \\
\text { decisions concerning their } \\
\text { own care }\end{array}$ & $\begin{array}{l}\text { Qualitative, non- } \\
\text { participant observation }\end{array}$ & $\begin{array}{l}n=24 \text { children, } \\
\text { aged } 5 \text { months- } \\
18 \text { years }\end{array}$ & $\begin{array}{l}\text { Acute and } \\
\text { chronic }\end{array}$ \\
\hline $\begin{array}{l}\text { Runeson et al. (2002b), } \\
\text { Sweden }\end{array}$ & $\begin{array}{l}\text { To learn, through observation, } \\
\text { about children's needs during } \\
\text { hospitalisation when interacting } \\
\text { with their parents and staff } \\
\text { members }\end{array}$ & $\begin{array}{l}\text { Qualitative, non- } \\
\text { participant observation }\end{array}$ & $\begin{array}{l}n=21 \text { boys, aged } \\
5 \text { months }-16 \text { years }\end{array}$ & $\begin{array}{l}\text { Acute and } \\
\text { chronic }\end{array}$ \\
\hline $\begin{array}{l}\text { Runeson et al. (2007), } \\
\text { Sweden }\end{array}$ & $\begin{array}{l}\text { To investigate children's level of } \\
\text { knowledge regarding a current } \\
\text { diagnostic procedure and the level } \\
\text { of participation in discussions } \\
\text { and decision-making relating to } \\
\text { their hospitalisation }\end{array}$ & $\begin{array}{l}\text { Qualitative semi-structured } \\
\text { interviews }\end{array}$ & $\begin{array}{l}n=23 \text { children, } \\
\text { aged } 6-11\end{array}$ & Acute \\
\hline Sartain et al. (2000), UK & $\begin{array}{l}\text { Explore children's, parents' and } \\
\text { health professionals' experience } \\
\text { of childhood chronic illness }\end{array}$ & $\begin{array}{l}\text { Qualitative, semi-structured } \\
\text { interviews }\end{array}$ & $\begin{array}{l}n=7 \text { families, } \\
\text { children aged } 8-14, \\
\text { and their professional } \\
\text { carers }\end{array}$ & Chronic \\
\hline $\begin{array}{l}\text { van Dulmen (1998), } \\
\text { Netherlands }\end{array}$ & $\begin{array}{l}\text { To examine how children } \\
\text { contribute to communication } \\
\text { during outpatient encounters } \\
\text { and what factors are associated } \\
\text { with children's contributions }\end{array}$ & $\begin{array}{l}\text { Quantitative, videotaping } \\
\text { of outpatient encounters }\end{array}$ & $\begin{array}{l}n=21 \text { consulting } \\
\text { paediatricians, } \\
n=302 \text { outpatient } \\
\text { encounters, mean age } \\
5 \cdot 3 \text { years }\end{array}$ & $\begin{array}{l}\text { Acute and } \\
\text { chronic }\end{array}$ \\
\hline
\end{tabular}


Table 1 (Continued)

\begin{tabular}{|c|c|c|c|c|}
\hline Author, date, country & Research question/aim & $\begin{array}{l}\text { Research approach and } \\
\text { methods }\end{array}$ & Participants & $\begin{array}{l}\text { Acute/chronic } \\
\text { illness }\end{array}$ \\
\hline Young et al. (2003), UK & $\begin{array}{l}\text { To examine young people's and } \\
\text { parents' accounts of } \\
\text { communication about cancer } \\
\text { in childhood }\end{array}$ & $\begin{array}{l}\text { Qualitative, semi-structured } \\
\text { interviews }\end{array}$ & $\begin{array}{l}n=13 \text { children, } \\
\text { aged } 8-17, \text { and } \\
n=19 \text { parents }\end{array}$ & $\begin{array}{l}\text { Chronic, life } \\
\text { threatening }\end{array}$ \\
\hline Young et al. (2006), UK & $\begin{array}{l}\text { To explore children's, parents' and } \\
\text { practitioners' accounts of shared } \\
\text { decision-making in the context of } \\
\text { community-based physiotherapy } \\
\text { services for children with cerebral } \\
\text { palsy }\end{array}$ & $\begin{array}{l}\text { Qualitative, semi-structured } \\
\text { interviews (children and } \\
\text { parents) } \\
\text { Focus groups } \\
\text { (physiotherapists) }\end{array}$ & $\begin{array}{l}n=11 \text { children, } \\
\text { aged } 8-18 \text { and } \\
n=2 \text { parents } \\
n=10 \text { physiothera- } \\
\text { pists }\end{array}$ & Chronic \\
\hline
\end{tabular}

*Author contacted directly for information of the ages of the children interviewed as not available in published report.

\section{Results}

\section{Do children want to participate in decision-making?}

In two observational studies, children verbally expressed a desire to be more involved in communication processes and decision-making (Bjork et al. 2006, Lambert et al. 2008). Lambert et al. (2008) note that there are times when children choose to be less involved, for example, in the case of one child who is in pain. Alderson (1993), in her study of children and decision-making, found that the majority of children favoured joint decision-making involving parents and health professionals as well as themselves. More recent research also suggests that young people prefer not to be left to make decisions without support (Kelsey et al. 2007, Runeson et al. 2007). There is very little research, however, which directly asks children whether they want to be involved in decision-making. Most studies, providing understanding on children's views of participation, explore more generally their experiences in communicating with health professionals.

Children report that they feel valued and less anxious about what is happening when they are included in discussions and asked directly about their treatment (Dixon-Woods et al. 2002, Kelsey et al. 2007). Conversely, when not included, children often feel angry and upset (Noyes 2000, Sartain et al. 2000, Carter 2002, Beresford \& Sloper 2003, Young et al. 2003, Coyne 2006, Kelsey et al. 2007). It can appear to children that health professionals are not interested in their views or their particular concerns and that they prefer instead to talk to their parents; sometimes asking parents the same questions as they have asked the child, thus devaluing their contribution (Coyne 2006). These findings suggest that children and young people do want to be involved to some degree in decision-making processes.

\section{The extent of participation in practice}

Examination of the literature reveals that the body of available evidence which seeks to establish the extent to which children are involved in actual decision-making processes is notably small. Researchers have examined the lived experience of participants by interviewing children sometimes separately and sometimes with their parents (Beresford \& Sloper 2003, Carter 2002, Coyne 2006, Noyes 2000, Runeson et al. 2000, Runeson et al. 2007, Sartain et al. 2000, Young et al. 2003, 2006). In addition, non- or semi-participant observation and video taping of consultations have also been used to investigate the participation of children in practice (Cox et al. 2007, Cox \& Raaum 2008, Cox et al. 2009, Hallstrom \& Elander 2004, Lambert et al. 2008, Runeson et al. 2002a,b, van Dulmen 1998).

In studies where children have been interviewed, they report varying experiences of being consulted and involved in decisions. Some tell of positive experiences citing instances where their opinions were sought by health professionals (Runeson et al. 2000, Coyne 2006). Conversely, other studies report that there are times when children feel excluded and ignored during encounters with health professionals (Sartain et al. 2000, Noyes 2000, Dixon-Woods et al. 2002, Carter 2002, Beresford \& Sloper 2003, Young et al. 2003, Coyne 2006, Kelsey et al. 2007). Runeson et al. (2007) investigated the extent of participation in decision-making in 23 children who were aged between 6-11 and who had been admitted for a planned procedure. Fourteen children reported that they had not participated in any discussions or decisions whilst nine reported that they had been asked whether they wanted to undergo the procedure.

Observation of children in hospital also suggests varying degrees of participation in decision-making (Runeson et al. 2002a, Hallstrom \& Elander 2004, Lambert et al. 2008). 
Two papers report the findings from a single research study that used non-participant observation to describe the degree to which children were involved (Runeson et al. 2002a, Hallstrom \& Elander 2004), the types of decisions they were involved in, and how these were made during hospitalisation (Hallstrom \& Elander 2004). They concluded that children are not always given the opportunity to be involved in decision-making processes to a desirable level. The age of the children in the study ranged from five months -18 years with a mean age of $6 \cdot 5$; seven children were aged three or under $(n=24)$. In the light of the age profile of this sample, it is perhaps not surprising that the results indicate that children are not always allowed to participate to an 'optimal' extent which is defined by the authors as situations where the children receive information, take part in decision-making and sometimes bring about compromises in the original plan of treatment (Runeson et al. 2002a, p. 593).

Another point worthy of note is that in Runeson et al.'s study (2002a) there is wide disparity in the types of decisions which are observed and graded on a self-determination scale. Level five applies to a situation where the member of staff acts in accordance with the child's wishes and this is reported as occurring in 48 of 137 situations. It is notable however that these decisions were in the main 'soft' decisions relating to issues such as how they would like to pass the time, what they would like to eat and drink, and whether their parents should be close by. Conversely, level four, where the member of staff acts only partially in accordance with the child's wishes, accounted for 17 of the situations. Over half of these decisions related to participation in examinations and taking samples for tests. Clearly, there is a danger here that tokenistic forms of participation are being interpreted as meaningful, that is children are viewed as having a say in decisions which do not make any overall difference to their care or treatment. This perhaps highlights a broader issue of the difficulty for researchers in defining participation.

Both this study and that carried out by Runeson et al. (2000) analyse the data using an instrument which describes five levels of self-determination. However, the reliability and validity of the instrument is not reported which also affects the credibility of the findings. In another study, outpatient consultations between children and their parents and paediatricians were videotaped and analysed quantitatively. Children's contributions to the consultation were limited to $4 \%$ with only one of every four statements being directed to the child (van Dulmen 1998). It was noted that $54 \%$ of paediatricians' social communication behaviours are directed to the child in contrast with $18 \%$ of their medical statements, that is doctors will interact socially with children, but when it comes to discussion of their care and treatment they will frequently direct this to the parents. This study provides useful quantitative data which reveal how children may be marginalised in consultations and is supported by Cox et al. (2007) and Cox and Raaum (2008) who also videotaped consultations. The authors concluded that the involvement of children in discussions around aspects of treatment and in processes which led to a decision being made was, in the main, passive.

\section{Barriers to participation}

The literature reveals several ways effective participation can be hindered. Coyne's study (2006) identified problems caused by deficiencies in the verbal and non-verbal communication skills of health professionals, for example, the use of nonchild-friendly medical terminology and jargon and speaking over the child to the parents. This may result in children not being given, or not understanding, the information which they need to be able to play a meaningful role in the consultation process.

Research into the experiences of adolescents with longterm conditions found that there is a perception that doctors are not interested in the wider effects of their condition on their everyday lives (Beresford \& Sloper 2003). This can result in a reluctance to discuss difficulties at school or raise personal issues which might reveal problems with their adherence to treatment (Beresford \& Sloper 2003). Consequently, the child remains instrumentally outside the consultation process as their real concerns remain hidden.

It has also been identified that differing styles of parenting may affect the extent to which the child or young person participates in the consultation process. In one study children describe how parents can dominate appointments making it difficult for them to contribute (Beresford \& Sloper 2003). Conversely, young people, who are able to make their own decisions, report being worried about their parents feeling excluded (Kelsey et al. 2007). The passivity of children can also be reinforced by parents who interrupt and block interaction between doctor and child (Lambert et al. 2008), parents who undermine their child's story (Sartain et al. 2000) or by doctors who ask parents the same questions they have already asked the child (Coyne 2006). Videotaping of consultations also showed that parents frequently answer questions which are directed at the child (van Dulmen 1998). This was further substantiated in a study where parents reported that they frequently speak for their child in a form of 'adult-child ventriloquism' (Carter 2002, p. 35). In addition, there is some evidence to suggest that parents are less likely to encourage their children to be involved if the consequences of 
making the wrong decision are perceived to be great and more inclined to withhold information from their children to protect them at difficult times, for example at diagnosis (Angst \& Deatrick 1996, Young et al. 2003). This is also reflected in Runeson et al.'s study (2002a) that found children were able to participate more in 'soft' decisions than those which made little overall difference to the outcome of care or treatment.

Adolescents have also reported that they themselves may negatively affect communication because of their lack of the necessary skills, for example not knowing how to ask questions (Beresford \& Sloper 2003). This and other practical aspects such as lack of time during the consultation, the presence of students, concerns of the child in relation to confidentiality and privacy and language difficulties have also been highlighted as presenting barriers to participation (Beresford \& Sloper 2003, Runeson et al. 2001).

In addition, the need to protect children, as embodied in the best interests principle central to both the Children Act 1989 and the United Nations 1989, can be used to deny children their rights to self-determination and autonomy. Bricher (2000) discusses the tension for paediatric nurses between acting in a child's best interests and upholding their rights to self-advocacy, noting that ultimately the best interest principle can be used against children to override their wishes. Thus, when children protest against treatment, nurses report that they try to elicit cooperation but if this fails they will proceed anyway (Bricher 2000).

\section{Enablers of participation}

Several factors have been identified which can promote the participation of children and young people in decisionmaking. Studies have found that the presence of parents can facilitate their child's involvement as the child may feel more confident and able to take a more active role in the consultation process (Beresford \& Sloper 2003, Young et al. 2003). In addition, parental approval of child participation further enables nurses in facilitating this (Coyne 2006). A recent study, where consultations were videotaped, also found that the children of educated parents are more likely to be actively involved in consultations (Cox \& Raaum 2008).

Coyne (2006) suggests that children who are more knowledgeable and informed about their condition, care and treatments are also more likely to be involved in decisionmaking with more weight being accorded to their views by parents and health professionals. This will primarily include children with long-term conditions and is supported by Alderson et al. (2006) who found that children with diabetes were able to make informed decisions about their treatment from around the age of four. This increased participation mirrors that reported by this group of children's parents who have been noted to take more active participative roles in caring for their children (Casey 1995). In addition, the 'literate public' described by Neuberger $(2000$, p. 7$)$ includes children and young people who are able to access information about their illnesses in the same way, or even better than, adult patients.

Age and maturity have also been noted to influence the degree to which children are involved in decision-making. Runeson et al. (2001) noted that children of school age can play a constructive role in discussions with health professionals so that decisions can be made which are favourable to both sides. Direct communication about care and treatment between doctor and child in consultations has also been seen to increase with the age of the child (van Dulmen 1998, Cox et al. 2009). However, Lambert et al. (2008) point out the difficulties of using age and prior experience as criteria for participation with findings in their observational study suggesting that both factors do not necessarily have any influence on the degree to which children participate in the communication process.

The gender of the child has also been shown to have an effect although there are conflicting findings. In one study, where children were videotaped in consultations with paediatricians, boys were found to have a more active communication attitude towards the doctor despite the fact that they tended to be younger than the girls in the study (van Dulmen 1998). Conversely, Cox et al. (2007) report that boys were less involved in decision-making processes. In addition, protest from the child can lead to decisions being reconsidered; for example, Hallstrom and Elander (2004) report a situation where a child who has had a suppository refuses to have another. His refusal is upheld and the authors point out that situations where a child protests physically, for example by kicking, screaming or struggling, are difficult to handle and can make it impossible to proceed with treatment.

Cox and Raaum (2008) noted that active involvement of children in discussions about treatment was more likely with experienced doctors. Children's nurses, who advocate for children and their rights to self-determination, may also promote the participation of children and young people (Hallstrom \& Elander 2004). Sometimes parents are considered to be the prime advocate, but their emotional involvement with the child may make it more difficult for them to facilitate their child's involvement in decisionmaking, particularly if they are afraid they will make what parents perceive to be wrong decisions (Hallstrom \& Elander 2004). 


\section{Benefits of participation}

Research examining the benefits of participation appears to focus largely on process rather than outcomes of participation. This review revealed studies where children reported feeling valued when included in discussions about their treatment and symptoms (Angst \& Deatrick 1996, DixonWoods et al. 2002). Parents in Coyne's study (2006) felt that respecting their children's abilities increased their self-esteem and accrued to them positive self-regard, thus enhancing their overall welfare. In addition, parents felt that health professionals have varying standards of practice and levels of expertise; allowing their child to be involved in how care is delivered helps to maintain consistency for the child as well as ensure that their preferences are taken into account (Coyne 2006). Although the process of decision-making appears to have clear benefits for the child, there is a paucity of evidence in terms of outcomes, that is, whether or not the involvement of children results in decisions being made which improve health and social outcomes.

\section{Disadvantages of participation}

Participation is a right which children are entitled to and much of the literature focuses on the realisation of this right. Notwithstanding this it would seem appropriate that, in so doing, due attention is paid to the ethical principle of nonmaleficence to ensure that the process and outcomes of participation do not harm the child in any way (McNeish 1999). For example, children may feel coerced or under pressure to participate, as adults increasingly expect them to be involved in decision-making processes (McNeish 1999, Terry \& Campbell 2001). In addition, concerns have been voiced regarding the negative effects on children of tokenism that is where they take part but have no influence on the decision and in child-adult relationships with suggestions that increased participation may lead to a lack of respect for adults (Lansdown 2001). Although there is expert commentary on the potential disadvantages to children of participation, as discussed earlier, no research has been identified which specifically looks at disadvantages in terms of both process and outcomes.

\section{Discussion}

The right of children and young people to have their say in decisions and actions which concern them is clearly set out in international human rights legislation and UK legislation and policy (UNCRC 1989, Children Act 1989, The Children's NSF). The realisation of this right in the UK can be problematic because of the overarching principle in the Children Act 1989 and Children Act 2004 that the best interests of the child are given primacy at all times. Problems can, therefore, arise when the child's wishes conflict with what adults consider to be in their best interests. Although research suggests that children can demonstrate competence in decision-making, the best interests principle creates conflict for practitioners who wish to promote children's participation but who remain acutely aware of their duty to protect children and young people in their care. Situations where the views of children are sought but then not necessarily taken into account when decisions are made are described as tokenistic and are not considered to be meaningful participation (Hart 1992). The argument, however, that this kind of involvement has no value because the child does not have the ultimate say is perhaps too simplistic for the complexities and nuances of decision-making processes encountered in health care. In addition, it is suggested that such a rigid stance is somewhat discouraging for practitioners who do indeed want to ensure that children and young people can play an appropriate role in decision-making, but who, at the same time, must act in the best interests of the child at all times. This creates difficulties and dilemmas for parents and professionals working with children (McNeish 1999) who, to facilitate children's rights to self-determination, must take on a role which is more than that of protector and provider (Kirby et al. 2003). Indeed, Roche (2002) suggests that a 'rethinking and redefining' (p. 72) of relationships between adult and child is now necessary in the approach to children's rights. The traditional approach of 'we know what's best' can no longer dominate discourse between adult and child.

This review has identified a body of research which suggests that young people wish to be involved in discussions about their care and to be listened to and respected. Feeling valued is identified as a positive effect of this approach (Angst \& Deatrick 1996, Dixon-Woods et al. 2002), but the extent to which children and young people participate in decisionmaking processes in practice remains unclear. Researchers have, in the main, attempted to elicit this information by interviewing children and their parents. However, varying expectations and experiences of children and young people are likely to affect their views on participation and thus interviews can only partially illuminate what is actually happening in practice.

Charles et al. (1999) highlight some of the difficulties of involving adults in decision-making in health care. Clearly, the health professional who tries to involve children will face even more challenges. This review has revealed some of the factors which facilitate and hinder participation and which can inform health professionals on how they can change their 
practice to promote the participation of children. These include ensuring privacy for children, sharing information, using appropriate communication and promoting a culture where children and young people are listened to.

This review has found that, thus far, the research on children's and young people's participation has mainly focussed on the views and experiences of children, parents and health professionals. Interviewing children and their parents reflects the current emphasis on seeking user perspectives in the NHS as well as the growing recognition that children too have a right to be consulted on matters relating to themselves (Davis 1998, Grover 2004, Neill 2005). It is suggested that, whilst interviews are essential in gaining subjective views, an over-reliance on interviewing as a method to collect data has led to gaps in the knowledge on the practice of participation. Thus, researchers have provided knowledge on children's perceptions of their communication with health professionals, as well as those of parents and health care staff, but we know little about what actually happens during that communication. For example, why children may be sometimes involved in decision-making and other times not, what factors affect participation and the overall extent to which meaningful participation happens in practice. Consequently, there remains a lack of evidence on whether, and to what degree, children's rights to have their say in decisions about their health care and treatment are being honoured in everyday nursing practice.

In addition, there are other methodological issues which have been highlighted in this review. Some studies consider decisions which differ vastly in importance in terms of risk, including those which carry significant implications for a child's long-term health and well-being (for example clinical investigations and treatment) and those which do not (for example food, play activities). This arguably diminishes the value of the research and leads to variable interpretations of participation as so-called 'soft' decisions are presented as the child being meaningfully involved in decision-making. Whilst it is recognised that such decisions can be very important to a child in terms of encouraging their involvement, it is suggested that research into participation would be enhanced by greater differentiation between the types of decisions under scrutiny. In addition, some studies have examined children across a large age range, for example five months18 years (Runeson et al. 2002a); three months-17 years old (Cox et al. 2007). The lower age ranges are inappropriate and again compromise the validity of the research. It is therefore suggested that, for research to be meaningful and relevant, decisions of similar importance should be considered and children should be of an age when participation would be appropriate, perhaps in age groups such as foursix, 7-11 years and young adolescents.

Clearly, further research is needed on several issues including the extent to which participation occurs, contributing factors to the success or failure of this policy and the long-term outcomes for the child. It is suggested that studies using observation as the principle method of data collection, along with interviews, would provide a deeper understanding of the interactional processes involved in promoting children's autonomy in health care.

\section{Conclusion}

Practitioners need evidence-based guidance on what helps or hinders the process of participation. Clinical governance places an explicit obligation on health professionals to continuously improve the quality of their services in order that the patient remains central to the care process (Scally $\&$ Donaldson 1998). To this end, care should be carried out with reference to the available research evidence as it is only by examining the evidence, and bringing about change where appropriate, that nurses can ensure that their practice is truly evidence based and maximally sensitive to the needs of the patient (RCN 2003).

This review differs from other reviews on decision-making (for example, Coyne 2008, Martenson \& Fagerskiold 2008) by its critical examination of how participation has been conceptualised and operationalised by researchers. This has revealed some key methodological issues in the research in relation to the age groups studied, methods used and types of decisions compared.

\section{Relevance to clinical practice}

In summary, this review has revealed that currently there is a lack of evidence on the participation of children and young people. Further research would help to raise awareness of this aspect of children's nursing and encourage practitioners to consider their everyday practice so that participation becomes a concept which exists in reality and not merely in the rhetoric of government and nursing policy. In addition, a clearer picture of the extent to which children are involved in discussions and decision-making on care and treatment would enable practitioners to judge whether children's rights to self-determination are being recognised in health care. Until practitioners have recourse to such evidence to guide them, the participation of children is likely to remain at the behest of individual health professionals and their personal views of children as actors in their own lives. If this is the case, it is likely that the interpretation of 
this key principle of modern health care will continue to vary.

\section{Contributions}

Study design: LM, SK; data collection and analysis: LM and manuscript preparation: LM, SK.

\section{Conflict of interest}

The author(s) declare that they have no conflict of interests.

\section{References}

Alderson P (1993) Children's Consent to Surgery. Open University Press, Buckingham.

Alderson P (2002) Young children's health care rights and consent. In The New Handbook of Children's Rights: Comparative Policy and Practice (Franklin B ed.). Routledge, London, pp. 155-167.

Alderson P, Sutcliffe K \& Curtis K (2006) Children as partners with adults in their medical care. Archives of Disease in Childhood 91, 300-303.

Angst DB \& Deatrick JA (1996) Involvement in health care decisions: parents and children with chronic illness. Journal of Family Nursing 2, 174-194.

Baxter R, Long A \& Sines D (1998) The legal and ethical status of children in health care in the UK. Nursing Ethics 5, 189-199.

Beidler SM \& Dickey SB (2001) Children's competence to participate in healthcare decisions. Jona's Healthcare, Law, Ethics and Regulation 3, 80-87.

Beresford BA \& Sloper P (2003) Chronically ill adolescents' experiences of communicating with doctors: a qualitative study. Journal of Adolescent Health 33, 172-179.

Bjork M, Nordstrom B \& Hallstrom I (2006) Needs of young children with cancer during their initial hospitalization: an observational study. Journal of Pediatric Oncology Nursing 23, 210219.

Bricher G (2000) Children in the hospital: issues of power and vulnerability. Pediatric Nursing 26, 277-292.

Carter B (2002) Chronic pain in childhood and the medical encounter: professional ventriloquism and hidden voices. Qualitative Health Research 12, 28-41.

Casey A (1995) Partnership nursing: influences on involvement of informal carers. Journal of Advanced Nursing 22, 1058-1062.

Charles C, Whelan T \& Gafni A (1999) What do we mean by partnership in making decisions about treatment? British Medical Journal 319, 780-782.

Children Act 1989. HMSO, Oxford.

Children Act 2004. The Stationery Office Limited, London.

Coulter A (2004) The evidence speaks for itself...but can the public? Nursing Management 11, 12-13.

Cox ED \& Raaum SE (2008) Discussion of alternatives, risks and benefits in pediatric acute care. Patient Education and Counseling 72, 122-129.

Cox ED, Smith MA \& Brown RL (2007) Evaluating deliberation in pediatric primary care. Pediatrics $120,68-77$.
Cox ED, Smith MA, Brown RL \& Fitzpatrick MA (2009) Learning to participate: effect of child age and parental education on participation in pediatric visits. Health Communication 24, 249258.

Coyne I (2006) Consultation with children in hospital: children, parents' and nurses' perspectives. Journal of Clinical Nursing 15, 61-71.

Coyne I (2008) Children's participation in consultations and decision-making at health service level: a review of the literature. International Journal of Nursing Studies 45, 1682-1689.

Davis JM (1998) Understanding the meanings of children: a reflexive process. Children and Society 12, 325-335.

Department of Health (2000) The NHS Plan. HMSO, London.

Department of Health (2001) The Expert Patient: A New Approach to Chronic Disease Management for the 21st Century. HMSO, London.

Department of Health; Department for Education and Skills (2004) National Service Framework for Children, Young People and Maternity Services: Core Standards. Available at: http:// www.dh.gov.uk/en/Publicationsandstatistics/Publications/PublicationsPolicyAndGuidance/DH_4089099 (accessed 20 January 2008).

Dixon-Woods M, Anwar Z, Young B \& Brooke A (2002) Lay evaluation of services for childhood asthma. Health and Social Care in the Community 10, 503-511.

van Dulmen AM (1998) Children's contributions to pediatric outpatient encounters. Pediatrics 102, 563-568.

Grover S (2004) Why won't they listen to us: on giving power and voice to children participating in social research. Childhood 11, 81-93.

Hallstrom I \& Elander G (2004) Decision-making during hospitalisation: parents' and children's involvement. Journal of Clinical Nursing 13, 367-375.

Hart RA (1992) Children's Participation: From Tokenism to Citizenship. UNICEF Child Development Centre, Florence.

James A \& James AL (2004) Constructing Childhood: Theory, Policy and Social Practice. Palgrave Macmillan, Hampshire.

Kelsey J, Abelson-Mitchell N \& Skirton H (2007) Perceptions of young people about decision making in the acute healthcare environment. Paediatric Nursing 19, 14-18.

Kirby P, Lanyon C, Cronin K \& Sinclair R (2003) Building a Culture of Participation: Research Report. DfES Publications, Nottingham.

Lambert V, Glacken M \& McCarron M (2008) 'Visible-ness': the nature of communication for children admitted to a specialist children's hospital in the Republic of Ireland. Journal of Clinical Nursing 17, 3092-3102.

Lansdown G (2000) Implementing children's rights and health. Archives of Disease in Childhood 83, 286-288.

Lansdown G (2001) Promoting Children's Participation in Democratic Decision-Making. UNICEF Innocenti Research Centre, Italy.

Lightfoot J \& Sloper P (2003) Having a say in health: involving young people with a chronic illness or physical disability in local health services development. Children and Society 17, 277-290.

Martenson EK \& Fagerskiold AM (2008) A review of children's decision-making competence in health care. Journal of Clinical Nursing 17, 3131-3141.

McNeish D (1999) Promoting participation for children and young people: some key questions for health and social welfare organisations. Journal of Social Work Practice 13, 191-203. 
Neill SJ (2005) Research with children: a critical review of the guidelines. Journal of Child Health Care 9, 46-58.

Neuberger J (2000) The educated patient: new challenges for the medical profession. Journal of Internal Medicine 247, 6-10.

Noyes J (2000) Enabling young 'ventilator-dependent' people to express their views and experiences of their care in hospital. Journal of Advanced Nursing 31, 1206-1215.

Roche J (2002) The Children Act 1989 and children's rights. In The New Handbook of Children's Rights: Comparative Policy and Practice (Franklin B ed.). Routledge, London, pp. 60-80.

Royal College of Nursing (2003) Clinical Governance: an RCN Resource Guide. Royal College of Nursing, London.

Runeson I, Elander G, Hermeren G \& Kristensson-Hallstrom I (2000) Children's consent to treatment: using a scale to assess degree of self-determination. Pediatric Nursing 26, 455-463.

Runeson I, Enskar K, Elander G \& Hermeren G (2001) Professionals' perceptions of children's participation in decision making in health care. Journal of Clinical Nursing 10, 70-78.

Runeson I, Hallstrom I, Elander G \& Hermeren G (2002a) Children's participation in the decision-making process during hospitalization: an observational study. Nursing Ethics 9, 583-598.

Runeson I, Hallstrom I, Elander G \& Hermeren G (2002b) Children's needs during hospitalization: An observational study of hospitalized boys. International Journal of Nursing Practice 8, 158-166.

Runeson I, Martenson E \& Enskar K (2007) Children's knowledge and degree of participation in decision making when undergoing a clinical diagnostic procedure. Pediatric Nursing 33, $505-512$.
Sartain S, Clarke C \& Heyman R (2000) Hearing the voices of children with chronic illness. Journal of Advanced Nursing 32, 913-921.

Scally G \& Donaldson LJ (1998) Clinical governance and the drive for quality improvement in the new NHS in England. British Medical Journal 317, 61-65.

Sinclair R (2004) Participation in practice: making it meaningful, effective and sustainable. Children and Society 18, 106-118.

Staniszewska S \& West E (2004) Meeting the patient partnership agenda: the challenge for healthcare workers. International Journal for Quality in Health Care 16, 3-5.

Terry L \& Campbell A (2001) Are we listening to children's views about their treatment? British Journal of Nursing 10, 384-390.

United Nations (1989) United Nations Convention on the Rights of the Child. United Nations, Geneva.

Weithorn LA \& Campbell SB (1982) The competency of children and adolescents to make informed treatment decisions. Child Development 53, 1589-1598.

Young B, Dixon-Woods M, Windridge KC \& Heney D (2003) Managing communication with young people who have a potentially life threatening chronic illness: qualitative study of patients and parents. British Medical Journal 326, 305.

Young B, Klaber Moffett J, Jackson D \& McNulty A (2006) Decision-making in community-based paediatric physiotherapy: a qualitative study of children, parents and practitioners. Health and Social Care in the Community 14, 116-124. 